\title{
Widespread Qol Fungicide Resistance Revealed Among Corynespora cassiicola Tomato Isolates in Florida
}

\author{
Keevan J. MacKenzie, ${ }^{1}$ Katia V. Xavier, ${ }^{1}$ Aimin Wen, ${ }^{1}$ Sujan Timilsina, ${ }^{2}$ Heather M. Adkison, ${ }^{1}$ Nicholas S. Dufault, ${ }^{2}$ \\ and Gary E. Vallad, ${ }^{1, \dagger}$ \\ ${ }^{1}$ University of Florida, Gulf Coast Research and Education Center, Wimauma, FL 33598 \\ ${ }^{2}$ Department of Plant Pathology, University of Florida, Gainesville, FL 32611
}

\begin{abstract}
Target spot of tomato caused by Corynespora cassiicola is one of the most economically destructive diseases of tomato in Florida. A collection of 123 isolates from eight counties in Florida were evaluated for sensitivity to azoxystrobin and fenamidone based on mycelial growth inhibition (MGI), spore germination (SG), detached leaflet assays (DLAs), and sequence-based analysis of the cytochrome b gene (cytb). Cleavage of $c y t b$ by restriction enzyme (Fnu4HI) revealed the presence of a mutation conferring a glycine $(\mathrm{G})$ to alanine $(\mathrm{A})$ mutation at amino acid position 143 (G143A) in approximately $90 \%$ of the population, correlating with quinone outside inhibitor $(\mathrm{QoI})$ resistance based on MGI $(<40 \%$ at $5 \mu \mathrm{g} / \mathrm{ml})$, SG $(<50 \%$ at 1 and $10 \mu \mathrm{g} / \mathrm{ml})$, and DLA $(<10 \%$ severity reduction). The mutation conferring a phenylalanine $(\mathrm{F})$ to leucine (L) substitution at position 129 (F129L) was confirmed in moderately resistant isolates (\#9, \#19, and \#74)

based on MGI ( 40 to $50 \%$ at $5 \mu \mathrm{g} / \mathrm{ml})$, SG $(<50 \%$ at $1 \mu \mathrm{g} / \mathrm{ml}$ and $>50 \%$ at $10 \mu \mathrm{g} / \mathrm{ml}$ ), and DLA ( $>10 \%$ and $<43 \%$ severity reduction) for both QoI fungicides, whereas sensitive isolates (\#1, \#4, \#7, \#28, \#29, \#46, \#61, \#74, \#75, \#76, \#91, \#95, and \#118) based on MGI $(>50 \%$ at $5 \mu \mathrm{g} / \mathrm{ml}), \mathrm{SG}(>50 \%$ at $1 \mu \mathrm{g} / \mathrm{ml}$ and $10 \mu \mathrm{g} / \mathrm{ml})$, and DLA ( $>50 \%$ severity reduction) correlated to non-mutation-containing isolates or those with a silent mutation. This study indicates that QoI resistance among $C$. cassiicola isolates from tomato is widespread in Florida and validates rapid screening methods using MGI or molecular assays to identify resistant isolates in future studies.

Keywords: chemical, Corynespora cassiicola, disease management, fungicide resistance, quinone outside inhibitor, Solanum lycopersicum, vegetables
\end{abstract}

Target spot of tomato, caused by Corynespora cassiicola, was first reported in Florida in 1972 (Blazquez 1972) and has become one of the state's most economically important fungal tomato pathogens. Within the last decade, the disease has been identified more frequently in the state, with increasing aggressiveness reported by tomato growers (MacKenzie et al. 2018; Schlub et al. 2007). Target spot can cause blighting of foliage, fruit damage, and postharvest rot if left unmanaged (Dixon et al. 2009; Fajola 1979). No viable host resistance is currently available in commercial tomato lines (Schlub et al. 2007); therefore, the most common method for control is through the use of protective fungicides throughout the season (MacKenzie et al. 2018; Pernezny et al. 1996; Schlub et al. 2007).

Pernezny et al. (1996) reported that target spot could reduce marketable yields of tomato by as much as $33 \%$ in the absence of protective fungicides. Corynespora cassiicola is recognized as a high-risk pathogen for fungicide resistance development (FRAC 2014), and resistance to several fungicide groups has been identified in the field and greenhouse (Date et al. 2004; Ishii 2006; Miyamoto et al. 2007, 2009). Among these fungicide groups are the quinone outside inhibitors (QoIs). QoIs are categorized as high risk for resistance development because of a highly site-specific mechanism of pathogen inhibition (FRAC 2015), and they specifically bind the quinol

${ }^{\dagger}$ Corresponding author: G. E. Vallad; gvallad@ufl.edu

Funding: Funding was provided by the Specialty Crop Block Grant Program, award 22983, through the Florida Department of Agriculture and Consumer Services with support from the Specialty Crop Foundation, a nonprofit organization in place to benefit Florida's fruit and vegetable industry; the Florida Fruit and Vegetable Association, dedicated to the diverse fruit and vegetable industry; and the Florida Tomato Committee, which represents tomato growers, packers, and repackers in Florida.

The author(s) declare no conflict of interest.

Accepted for publication 9 September 2019

(C) 2020 The American Phytopathological Society oxidation site of the cytochrome $b c l$ complex (complex III) in the electron transport chain to inhibit normal respiration (FernándezOrtuño et al. 2008; Vincelli 2002).

Azoxystrobin is currently the oldest QoI fungicide labeled for use on target spot of tomato (Vallad et al. 2017). It was registered in the United States by Zeneca Agrochemicals (Fresno, CA) in 1996, and in 2000, after the merger of Zeneca Agrochemicals and Novartis Agribusiness (Basel, Switzerland) to Syngenta AG (Basel, Switzerland), it was labeled for use on tomato as Quadris (Bartlett et al. 2002). It was initially efficacious for target spot control, but Pernezny et al. (2002) reported reduced performance for azoxystrobin in Florida field trials conducted in the fall of 2001. Since then, numerous field trials have reported azoxystrobin resistance (Paret et al. 2013; G. E. Vallad, personal communication). Another QoI fungicide called fenamidone was registered for use on tomato by Bayer CropScience AG (Monheim am Rhein, Germany) not long after azoxystrobin, but fenamidone is not currently labeled for use against target spot in Florida (Vallad et al. 2017). Fenamidone has a molecular structure distinct from that of azoxystrobin (Bartlett et al. 2002), although both azoxystrobin and fenamidone belong to the same Fungicide Resistance Action Committee (FRAC) group (\#11) based on biochemical mode of action (FRAC 2017).

Complete resistance to multiple QoI fungicides has been commonly attributed to a single-nucleotide polymorphism in the $c y t b$ gene conferring an amino acid change from $\mathrm{G}$ to $\mathrm{A}$ at position 143 (G143A) (Ma and Michailides 2005). The resistant phenotype associated G143A mutation has been documented in $>20$ pathogens worldwide (Ishii 2006), and the restriction enzyme Fnu4HI (= Ital) can be used to rapidly identify the G143A mutation via PCR-restriction fragment length polymorphism (PCR-RFLP) (Ishii 2006, 2009). Several minor mutations (F129L and G137R) have also been identified that elicit a quantitative and more moderate form of resistance (Sierotzki et al. 2007). A lack of cross-resistance to QoI fungicides has been identified in F129L mutants (Pasche et al. 2005), although the G143A mutation appears cross-resistant against all currently tested QoI chemistries (FRAC 2015). Resistance to QoI fungicides (FRAC group 11) could equate to a loss of efficacy in 9 
out of 19 systemic fungicides labeled for the control of target spot on tomato in Florida based on active ingredient (Vallad et al. 2017).

QoI resistance development in $C$. cassiicola has been identified in several cucumber studies (Date et al. 2004; Ishii et al. 2007; Miyamoto et al. 2009, 2010) and reported on tomato in Florida (Adkison 2012; Paret et al. 2013). Sensitivity shifts to azoxystrobin have been identified in many other crops and pathogens (Keinath 2009; Ma and Michailides 2003; Mondal et al. 2005; Pasche et al. 2004; Vawdrey 2008); however, no in-depth studies have been performed on $C$. cassiicola isolates from tomato to date. Grower demand has prompted this study through an increasing presence of $C$. cassiicola in Florida and the devastating consequences of inadequate chemical control in disease-favorable conditions. This study was conducted to characterize QoI resistance, determine the prevalence among $C$. cassiicola associated with outbreaks of target spot of tomato in Florida, and elucidate the molecular mechanisms of resistance.

\section{Materials and Methods}

Collection and storage of fungal isolates. A total of 123 monoconidial isolates of $C$. cassiicola were collected from eight counties in Florida between 2015 and 2017 (Fig. 1). Isolations were as single spores from sporulating leaf lesions or by plating surface-sterilized symptomatic tissue from fruits, leaves, and stems on a general isolation media, consisting of a half-strength potato dextrose agar (HS-PDA; $9.75 \mathrm{~g}$ of PDA, $1.6 \mathrm{~g}$ of agar) containing $100 \mu \mathrm{g} / \mathrm{ml}$ of streptomycin and $250 \mu \mathrm{g} / \mathrm{ml}$ of ampicillin, based on active ingredient (a.i.). All subsequent rates in this study were also based on a.i.

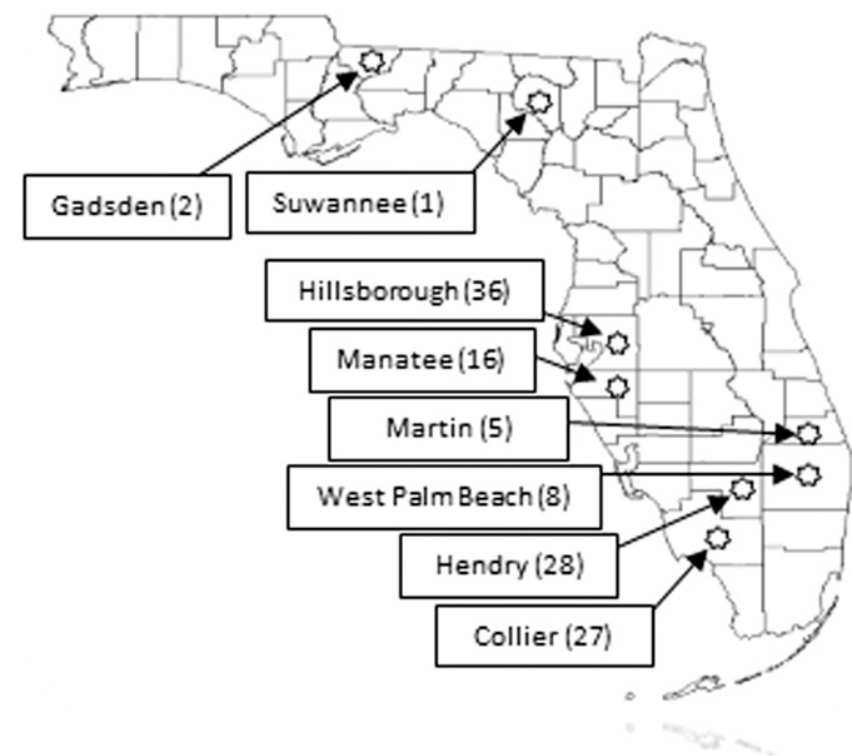

Fig. 1. Distribution of 123 Corynespora cassiicola isolates collected from 2015 to 2017 throughout eight important tomato-producing counties in Florida (numbers in parentheses indicate the number of isolates collected for that county).
All C. cassiicola isolates were identified based on their morphology, including obclavate to cylindrical pseudoseptate conidia with a highly distinctive hilum on its end, or at the point of conidiophore attachment (Ellis 1957; Qi et al. 2011). Thirteen representative isolates (Table 1) from different hosts and locations were selected to confirm C. cassiicola identity based on molecular characterization by sequencing the ribosomal DNA internal transcribed spacer (ITS). Genomic DNA from each isolate was used to perform PCRs with the primer pairs ITS1 (5'-TCCGTAGGTGAACCTGCGG-3') and ITS4 (5'-TCCTCCGCTTATTGATATGC-3') (White et al. 1990). The final volume for the PCR was $25 \mu \mathrm{l}$ containing: $25 \mathrm{ng}$ of genomic DNA, $10 \times$ PCR buffer, $50 \mathrm{mM}$ of $\mathrm{MgCl}_{2}, 200 \mu \mathrm{M}$ dNTPs, $1 \mathrm{U}$ of Taq DNA polymerase, and $5 \mu \mathrm{M}$ of each primer. The PCR cycling conditions were initial denaturation at $95^{\circ} \mathrm{C}$ for $3 \mathrm{~min}$, followed by 35 cycles of denaturation at $95^{\circ} \mathrm{C}$ for $1 \mathrm{~min}$, annealing for $30 \mathrm{~s}$ at $51^{\circ} \mathrm{C}$, extension at $72^{\circ} \mathrm{C}$ for $1 \mathrm{~min}$; with a final extension at $72^{\circ} \mathrm{C}$ for $10 \mathrm{~min}$. The amplified fragments were visualized on $1 \%$ agarose gel and then submitted to Elim Biopharmaceuticals, Inc. (Hayward, CA) for sequencing. Resulting forward and reverse sequences were aligned and the consensus sequence used to run BLASTn searches. A BLAST search in GenBank revealed that all 13 sequences showed $100 \%$ identity with $C$. cassiicola (Table 1 ). These sequences were also aligned with $C$. cassiicola sequences recovered from tomato plants previously identified by Dixon et al. (2009) (accession numbers FJ852574, FJ852575, FJ852678, FJ852679, and FJ852695 to FJ852697) and Sumabat et al. (2018) (accession numbers MF320502 to MF320506) and showed $>99.6 \%$ identity, confirming that our isolates belong to the species of $C$. cassiicola (Table 1).

For long-term storage, isolates were transferred to half strength (HS)-PDA and grown for 10 to 21 days $\left(25 \pm 2^{\circ} \mathrm{C}\right.$ and $12: 12$ photoperiod) with sterile filter paper squares placed surrounding the colony. When the mycelial mat fully colonized the plate, filter papers were removed, dried in a desiccator for 4 to 6 weeks, and stored in sterile envelopes at $-20^{\circ} \mathrm{C}$. Short-term isolate storage consisted of 5-mm HS-PDA agar plugs taken from the leading edge of 5- to 10day-old colonies and stored in 15-ml Falcon tubes of sterile deionized (DI) water at room temperature. Isolates collected from cucumber $(n=3)$, cotton $(n=2)$, and sesame $(n=1)$ in Florida were also included in this study as a sensitivity check.

Mycelial growth inhibition assays. Salicylhydroxamic acid (SHAM) is often included in in vitro experiments with QoI fungicides to inhibit the alternative oxidase pathway (Bradley and Pedersen 2011; Luo and Schnabel 2008; Secor and Rivera 2012; Sierotzki et al. 2000; Weber and Hahn 2011). An experiment was conducted with 10 C. cassiicola isolates $(2,4,7,10,17,19,20,22,24$, and 25) to determine the effect of SHAM on mycelial growth at $100 \mu \mathrm{g} / \mathrm{ml}$, which consisted of six reps and was conducted twice. Those 10 isolates were incorporated into a larger group of 29 C. cassiicola isolates representative of geographic location of isolation and differences in colony morphology and were subjected to HS-PDA amended with nine fungicide concentrations $(0,0.01,0.03,0.1$, $0.3,1,3,10$, and $100 \mu \mathrm{g} / \mathrm{ml}$ ) of commercial formulations of

Table 1. Representative $C$. cassiicola isolates used for species identification, confirmed by internal transcribed spacer (ITS) sequences

\begin{tabular}{|c|c|c|c|c|c|c|}
\hline Isolate number & Isolate name & Host & State & County & Year collected & ITS sequence accession \# \\
\hline 2 & GEV3125 & Tomato & Florida & Hendry & 2015 & MH806849 \\
\hline 4 & GEV3127 & Tomato & Florida & Hendry & 2015 & MH806850 \\
\hline 7 & GEV3130 & Tomato & Florida & Manatee & 2015 & MH806851 \\
\hline 13 & GEV3136 & Tomato & Florida & Hillsborough & 2011 & MH806852 \\
\hline 19 & GEV3142 & Tomato & Florida & West Palm Beach & 2016 & MH806853 \\
\hline 20 & GEV3143 & Tomato & Florida & West Palm Beach & 2016 & MH806854 \\
\hline 22 & GEV3145 & Tomato & Florida & Martin & 2016 & MH806855 \\
\hline 24 & GEV3148 & Tomato & Florida & Collier & 2016 & MH806856 \\
\hline 28 & GEV3154 & Cotton & Florida & Gadsden & 2015 & MH806857 \\
\hline 29 & GEV3155 & Sesame & Florida & Suwannee & 2015 & MH806858 \\
\hline 89 & GEV3219 & Cucumber & Florida & Hillsborough & 2015 & MH806859 \\
\hline 90 & GEV 3220 & Cucumber & Florida & Hillsborough & 2015 & MH806860 \\
\hline 91 & GEV3221 & Cotton & Florida & Gadsden & 2015 & MH806861 \\
\hline
\end{tabular}


azoxystrobin (22.9\% a.i.) and fenamidone (44.4\% a.i.) based on a.i. in the presence of SHAM $(100 \mu \mathrm{g} / \mathrm{ml})$. Azoxystrobin was included in the media in the presence and absence of SHAM in a separate experiment to determine potential inhibition of the alternative oxidase pathway in vitro (McIntosh 1994) at $100 \mu \mathrm{g} / \mathrm{ml}$.

A stock solution of $50,000 \mu \mathrm{g} / \mathrm{ml}$ was prepared by dissolving $50 \mathrm{mg}$ of SHAM per milliliter of $100 \%$ ethanol, which was added to amended and unamended media at $0.2 \%$ by volume $(100 \mu \mathrm{g} / \mathrm{ml}$ SHAM). Separate fungicide stock solutions containing 100 and $10,000 \mu \mathrm{g} / \mathrm{ml}$ of azoxystrobin and fenamidone were prepared in sterile DI water for dilution to final fungicide concentrations ranging from 0.01 to $0.3 \mu \mathrm{g} / \mathrm{ml}$ and 1 to $100 \mu \mathrm{g} / \mathrm{ml}$, respectively. Discriminatory dose screening used a stock solution of $2,500 \mu \mathrm{g} / \mathrm{ml}$ for dilution to one concentration $(5 \mu \mathrm{g} / \mathrm{ml})$ of each separate fungicide for the entire isolate population. SHAM $(100 \mu \mathrm{g} / \mathrm{ml})$ and fungicide stocks were added to the media at $55^{\circ} \mathrm{C}$, poured at approximately $20 \mathrm{ml}$ per Petri dish $(15 \times 85 \mathrm{~mm})$, and allowed to cool before transfers.

Isolate plugs were recovered from sterile water storage and grown for 4 to 7 days on HS-PDA at $25 \pm 2{ }^{\circ} \mathrm{C}$ and a $12: 12$ photoperiod of fluorescent light. Plugs $(5 \mathrm{~mm})$ were taken from the leading edge of each isolate colony and placed face down on fungicide-amended media. Four different isolates were grown on each plate for 4 days, and colony diameter measurements were taken. Plug size was subtracted from the final value, and the effective concentration at which $50 \%$ mycelial growth inhibition (MGI) is achieved $\left(\mathrm{EC}_{50}\right)$ was calculated. A discriminatory dose of $5 \mu \mathrm{g} / \mathrm{ml}$ for both fungicides was used to differentiate sensitive and resistant isolates based on percentage MGI. This experiment consisted of three replicates and was conducted twice. The two C. cassiicola isolates from cotton (28 and 91) and one from sesame (91) were included as possible sensitive isolates, because previous studies did not identify QoI-sensitive isolates from tomato (Adkison et al. 2012).

Spore germination assay. Four plugs from sterile water storage were transferred to full-strength PDA ( $39 \mathrm{~g}$ of PDA/liter) for 5 to 7 days in $25 \pm 2{ }^{\circ} \mathrm{C}$ and a $12: 12$ photoperiod under fluorescent light. Plates were scraped with the flat end of a steel spatula spoon to remove all mycelia and placed face-up under 24-h fluorescent light for 4 to 8 days, approximately $60 \mathrm{~cm}$ from the light source. Spores were collected by cutting 10- to $15-\mathrm{mm}$ squares from the media of sporulating cultures and shaking them in a sealed container with sterile DI water and one drop of Tween 20/100 ml. The spore suspension was filtered through a single layer of cheesecloth and quantified with a hemocytometer.

Before fungicide sensitivity assays for SG, the presence and absence of SHAM $(100 \mu \mathrm{g} / \mathrm{ml})$ was evaluated on 10 C. cassiicola tomato isolates $(2,4,7,10,17,19,20,22,24$, and 25). Total germ tube length was measured for 25 total spores in a repeated experiment for a total of 50 spores of each isolate to determine any potential deleterious effects of SHAM. Methods for SG were modified from Madhavi and Murthy's (2001) study on C. cassiicola rubber isolates. Fungicides were prepared at three separate concentrations of 0,1 , and $10 \mu \mathrm{g} / \mathrm{ml}$ for each isolate. The final concentration of SHAM was $100 \mu \mathrm{g} / \mathrm{ml}$ across all treatments, with a final spore concentration of $10^{3}$ spores per milliliter. Mixtures were prepared in $1.6-\mathrm{ml}$ microcentrifuge tubes and vortexed for $5 \mathrm{~s}$ before $50 \mu \mathrm{l}$ of each suspension was pipetted onto autoclaved cavity microscope slides. Each microscope slide contained two 18-mm-diameter cavities with 0.8 -mm depressions. Slides were placed in a humidity chamber with no cover slide, sealed, and incubated for $12 \mathrm{~h}$ (6-h fluorescent light and 6-h dark photoperiod) at $27^{\circ} \mathrm{C}$. Before the measurements were taken, all slides were placed in the refrigerator to limit further germ tube growth during the experiment. Observations were made on a compound microscope, with measurements taken with a digital camera equipped with the CellSens program.

For the experiment, total germ tube length was recorded for the first 25 conidia observed (12 from one cavity, 13 from the other), and the experiment was conducted four times for a total of 100 measurements per isolate-treatment-dose combination.

Sequence-based analyses of $c y t b$ gene. All fungal DNA isolations were performed via a modified Dellaporta method (Dellaporta et al. 1983). Fungal colonies were grown on HS-PDA for 7 to 10 days, when mycelia was scraped with a sterile toothpick and placed in a sterile 2-ml tube with Dellaporta buffer (100 mM Tris [pH 8], $500 \mathrm{mM}$ of $\mathrm{NaCl}, 50 \mathrm{mM}$ of EDTA, and $10 \mathrm{mM}$ of $\beta$-mercaptoethanol) and $10 \%$ (vol/vol) sodium dodecyl sulfate for homogenization. A 4-mm grinding ball was added to the tube and placed in a tissue homogenizer for two cycles of $30 \mathrm{~s}$ each $(1,500 \mathrm{rpm})$. Samples were then frozen at $-80^{\circ} \mathrm{C}$ for $10 \mathrm{~min}$ and incubated at $65^{\circ} \mathrm{C}$ for $15 \mathrm{~min}$ to release DNA from fungal cells, followed by adding potassium acetate ( $8 \mathrm{M})$, used for protein precipitation; isopropanol was used for nucleic acid precipitation, and $70 \%$ ethanol was used for cleaning the DNA pellet. The pellet was then resuspended in $1 \times$ TE buffer (10 $\mathrm{nM}$ Tris- $\mathrm{HCl}, 1 \mathrm{mM}$ EDTA. $\mathrm{Na}_{2}$ ) and stored at $-20^{\circ} \mathrm{C}$.

PCR amplification with $c y t b$ was initially undertaken with earlier described primers for $C$. cassiicola on cucumber, RSCBF1 and RSCBR2 (Ishii et al. 2007). No amplification could be achieved with these primers in our population; therefore, new primers specific for $c y t b$ analysis were designed (Table 2) based on predicted locations from the whole genome sequence of $C$. cassiicola isolate UM 591 collected from a contact lens (NCBI Assembly accession number GCA_000603925.1). PCR (25 $\mu \mathrm{l}$ reaction volume) included Promega (Madison, WI) GoTaq Green Master Mix 1X (1.25 units Taq DNA polymerase, $1.5 \mathrm{mM}$ of $\mathrm{MgCl}_{2}, 200 \mu \mathrm{M}$ dNTPs, and $1 \times$ reaction buffer), forward and reverse primers ( $4 \mu \mathrm{M}$ each), and DNA $(50 \mathrm{ng})$. PCR tubes were placed in a thermal cycler with an initial denaturation of $95^{\circ} \mathrm{C}$ for $2 \mathrm{~min}$, followed by 40 cycles of $95^{\circ} \mathrm{C}$ for $15 \mathrm{~s}$, $58^{\circ} \mathrm{C}$ for $30 \mathrm{~s}$, and $72^{\circ} \mathrm{C}$ for $30 \mathrm{~s}$, completed by a final elongation at $72^{\circ} \mathrm{C}$ for $5 \mathrm{~min}$. PCR products were digested with 150 units of Fnu4HI (=Ita 1$)$ at $37^{\circ} \mathrm{C}$ for $16 \mathrm{~h}$ (Ishii 2009; Ishii et al. 2007) and loaded onto $1.5 \%$ agarose gel with $1 X$ GelRed $^{\mathrm{TM}}$ (Biotium, Inc., Fremont, CA) in $1 \times$ Tris-borate-EDTA buffer, separated by electrophoresis, and visualized by transillumination with ultraviolet light. Before $F n u 4 \mathrm{HI}$ exposure, PCR products from $c y t b$ analysis were sent to Elim Biopharmaceuticals Inc for DNA sequencing, and BioEdit (version 7.2.6.1) was used for sequence assembly (Hall et al. 2011). Sequences were aligned with the predicted $c y t b$ gene from C. cassiicola isolate UM 591 (NCBI Assembly accession number GCA_000603925.1).

Detached leaflet assay. Tomato seedlings (FL-47) were grown in 128-cell flats for 4 weeks and transplanted to $15-\mathrm{cm}$ pots to grow for an additional 4 weeks. Twenty-four h before leaflet excision, the fourth newest leaf was dipped in Quadris $2.08 \mathrm{FL}(0.44 \mathrm{~kg}$ [a.i.]/ha) or Reason 500SC (0.29 kg [a.i.]/ha) based on the highest labeled broadcast volume for Florida tomatoes (280 liter/ha). Controls were dipped in sterile DI water. The first fully developed pair of leaflets from the main stem were excised at the petiole and placed abaxial side up in humidity chambers with wetted paper towels. Unraveled cotton balls were wetted and placed over excised petioles for maximum water retention. Each humidity chamber contained six treated and four untreated leaflets, and each leaflet was inoculated with four 7- $\mu$ l droplets. Six isolates were chosen based on MGI, SG, and mutation analyses that were indicative of sensitivity (7 and 125), moderate resistance (19 and 79), and resistance (2 and 93). The six isolates were randomly applied to detached leaflets at $10^{4}$ spores per milliliter, pipetted onto each abaxial leaflet surface. Water controls were concurrently randomized. Each isolate applied to three treated and two untreated leaflets and replicated five times for a total of 15 treated and 10 untreated leaflets per

Table 2. Sequences of primers designed for $c y t b^{z}$ analysis and primers from previously described $C$. cassiicola cucumber isolates

\begin{tabular}{lll}
\hline Primer name & Primer origin & Sequence $\left(5^{\prime}\right.$ to $3^{\prime}$ ) \\
\hline cct-cytb-F & This study & TATTATGCGGGATGTAAATAATGG \\
cct-cytb-R & This study & TAATGAGAAGAATCTATTTAATGTA \\
& & GCA \\
RSCBF1 & Ishii et al. 2007 & TATTATGAGAGATGTAAATAATGG \\
RSCBR2 & Ishii et al. 2007 & AACAATATCTTGTCCAATTCATGG \\
\hline
\end{tabular}

${ }^{\mathrm{z}} c y t b$ is a gene located in the region of the cytochrome $b c l$ complex associated with quinone outside inhibitor fungicide binding and inhibition. 
isolate per experiment, and the experiment was conducted twice. Disease severity was calculated based on lesion diameter (in millimeters) after 1 week in humidity.

Data analysis. $\mathrm{EC}_{50}$ values for MGI were calculated by regressing relative growth inhibition against the $\log _{10}$ of the fungicide concentrations and fitting them to a sigmoidal curve to interpolate the $50 \%$ inhibition intercept in GraphPad Prism 7. Independent experiments were assessed for homogeneity of variance with the covtest function in PROC GLIMMIX before combining. Discriminatory dose and SG data are observed as mean percentage inhibition relative to the control. A $t$ test was used to determine significance of detached leaf assays, and significant relationships were determined for \pm SHAM assays via Fisher's protected LSD $(\alpha=0.05)$. All data were evaluated in SAS 9.4.

\section{Results}

Mycelial growth inhibition. Initial assays conducted with $10 C$. cassiicola tomato isolates in the presence or absence of SHAM revealed a uniform reduction in mycelial growth across all isolates in the presence of SHAM (Table 3), but no isolates were severely inhibited. The MGI assays conducted in the absence of SHAM identified $\mathrm{EC}_{50}$ values $>100 \mu \mathrm{g} / \mathrm{ml}$ for azoxystrobin in all 29 preliminary isolates (Table 4). Preliminary screening in the presence of SHAM dramatically reduced $\mathrm{EC}_{50}$ values of seven isolates $(1,4,7,9,19$, 28 , and 29) for azoxystrobin (Table 4). Two characteristic groupings of sensitive $(<100 \mu \mathrm{g} / \mathrm{ml})$ and resistant $(>100 \mu \mathrm{g} / \mathrm{ml})$ isolates were revealed based on $\mathrm{EC}_{50}$ values for both fungicides. $\mathrm{EC}_{50}$ values for seven isolates $(1,4,7,9,19,28$, and 29) appeared sensitive to azoxystrobin (+SHAM) and fenamidone (+SHAM), with $\mathrm{EC}_{50}$ values $<100 \mu \mathrm{g} / \mathrm{ml}$. Azoxystrobin- and fenamidone-sensitive isolates exhibited mean $\mathrm{EC}_{50}$ values of $7.11 \pm 12.3$ (range $=0.22$ to $36.7 \mu \mathrm{g} / \mathrm{ml}$ ) and $13.0 \pm 10.56($ range $=3.86$ to $36.0 \mu \mathrm{g} / \mathrm{ml})$, respectively. The remaining 22 isolates were resistant, with $\mathrm{EC}_{50}$ values $>100 \mu \mathrm{g} / \mathrm{ml}$ for both fungicides (Table 4).

Upon observation of separations in preliminary dose-response results from 29 isolates (Fig. 2), a discriminatory dose of $5 \mu \mathrm{g} / \mathrm{ml}$ was used to differentiate sensitive ( $>40 \%$ inhibition) and resistant $(<40 \%$ inhibition) isolates. Screening all 123 isolates (Table 5) with the

Table 3. Mycelial growth inhibition (MGI) and spore germination (SG) of 10 C. cassiicola tomato isolates ${ }^{\mathrm{y}}$ in the presence and absence of salicylhydroxamic acid (SHAM)

\begin{tabular}{lccrl}
\hline Assay & Experiment & Water control $^{\mathbf{z}}$ & Ethanol $^{\mathbf{z}}$ & Ethanol + SHAM $^{\mathbf{2}}$ \\
\hline MGI, mm & 1 & $38.0 \mathrm{a}$ & $38.0 \mathrm{a}$ & $33.0 \mathrm{~b}$ \\
MGI, mm & 2 & $34.0 \mathrm{a}$ & $34.0 \mathrm{a}$ & $29.0 \mathrm{~b}$ \\
SG, $\mu$ m germ tube length & 1 & $211.0 \mathrm{a}$ & $200.0 \mathrm{a}$ & $198.0 \mathrm{a}$ \\
SG, $\mu$ m germ tube length & 2 & $226.0 \mathrm{a}$ & $224.0 \mathrm{a}$ & $220.0 \mathrm{a}$ \\
\hline
\end{tabular}

${ }^{y}$ C. cassiicola isolates $2,4,7,10,17,19,20,22,24$, and 25 were included in the assay.

${ }^{\mathrm{z}}$ Means in the same row followed by the same letter are not statistically different based on Fisher's protected LSD at the $95 \%$ level of confidence.

Table 4. Calculated $\mathrm{EC}_{50}$ values for azoxystrobin and fenamidone based on mycelial growth inhibition (MGI) for 29 Corynespora cassiicola isolates collected from tomato in Florida

$\operatorname{EC}_{50}(\mu \mathrm{g} / \mathrm{ml})^{\mathrm{x}}$

\begin{tabular}{|c|c|c|c|c|c|c|}
\hline Isolate number & Isolate name & County of origin & Sensitivity ratingy & Azoxystrobin - SHAMz & Azoxystrobin + SHAM & Fenamidone + SHAM \\
\hline 1 & GEV3124 & Hendry & $\mathrm{S}$ & $>100$ & 0.2 & 8.5 \\
\hline 2 & GEV3125 & Hendry & $\mathrm{R}$ & $>100$ & $>100$ & $>100$ \\
\hline 3 & GEV3126 & Hendry & $\mathrm{R}$ & $>100$ & $>100$ & $>100$ \\
\hline 4 & GEV3127 & Hendry & $\mathrm{S}$ & $>100$ & 1.8 & 9.7 \\
\hline 5 & GEV3128 & Hendry & $\mathrm{R}$ & $>100$ & $>100$ & $>100$ \\
\hline 6 & GEV3129 & Hendry & $\mathrm{R}$ & $>100$ & $>100$ & $>100$ \\
\hline 7 & GEV3130 & Manatee & $\mathrm{S}$ & $>100$ & 0.9 & 4.5 \\
\hline 8 & GEV3131 & Manatee & $\mathrm{R}$ & $>100$ & $>100$ & $>100$ \\
\hline 9 & GEV3132 & Manatee & S & $>100$ & 7.7 & 19.8 \\
\hline 10 & GEV3133 & Manatee & $\mathrm{R}$ & $>100$ & $>100$ & $>100$ \\
\hline 11 & GEV3134 & Manatee & $\mathrm{R}$ & $>100$ & $>100$ & $>100$ \\
\hline 12 & GEV3135 & Hillsborough & $\mathrm{R}$ & $>100$ & $>100$ & $>100$ \\
\hline 13 & GEV3136 & Hillsborough & $\mathrm{R}$ & $>100$ & $>100$ & $>100$ \\
\hline 14 & GEV3137 & Collier & $\mathrm{R}$ & $>100$ & $>100$ & $>100$ \\
\hline 15 & GEV3138 & Collier & $\mathrm{R}$ & $>100$ & $>100$ & $>100$ \\
\hline 16 & GEV3139 & Collier & $\mathrm{R}$ & $>100$ & $>100$ & $>100$ \\
\hline 17 & GEV3140 & Collier & $\mathrm{R}$ & $>100$ & $>100$ & $>100$ \\
\hline 18 & GEV3141 & Palm Beach & $\mathrm{R}$ & $>100$ & $>100$ & $>100$ \\
\hline 19 & GEV3142 & Palm Beach & $\mathrm{S}$ & $>100$ & 36.7 & 36.0 \\
\hline 20 & GEV3143 & Palm Beach & $\mathrm{R}$ & $>100$ & $>100$ & $>100$ \\
\hline 21 & GEV3144 & Martin & $\mathrm{R}$ & $>100$ & $>100$ & $>100$ \\
\hline 22 & GEV3145 & Martin & $\mathrm{R}$ & $>100$ & $>100$ & $>100$ \\
\hline 23 & GEV3147 & Collier & $\mathrm{R}$ & $>100$ & $>100$ & $>100$ \\
\hline 24 & GEV3148 & Collier & $\mathrm{R}$ & $>100$ & $>100$ & $>100$ \\
\hline 25 & GEV3150 & Collier & $\mathrm{R}$ & $>100$ & $>100$ & $>100$ \\
\hline 26 & GEV3151 & Collier & $\mathrm{R}$ & $>100$ & $>100$ & $>100$ \\
\hline 27 & GEV3153 & Hillsborough & $\mathrm{R}$ & $>100$ & $>100$ & $>100$ \\
\hline 28 & GEV3154 & Gadsden & S & $>100$ & 0.7 & 8.6 \\
\hline 29 & GEV3155 & Suwannee & S & $>100$ & 1.8 & 3.9 \\
\hline
\end{tabular}

${ }^{\mathrm{x}} \mathrm{EC}_{50}=$ effective concentration at which mycelial growth is inhibited by $\geq 50 \%$ relative to the control. Azoxystrobin was derived from Quadris 2.08 FL and fenamidone from Reason $500 \mathrm{SC}$.

${ }^{y} \mathrm{R}$, resistant $\left(\mathrm{EC}_{50}>100 \mu \mathrm{g} / \mathrm{ml}\right) ; \mathrm{S}$, sensitive $\left(\mathrm{EC}_{50}<100 \mu \mathrm{g} / \mathrm{ml}\right)$.

${ }^{\mathrm{z}}$ SHAM, salicylhydroxamic acid. 
$5-\mu \mathrm{g} / \mathrm{ml}$ discriminatory dose of azoxystrobin and fenamidone in the presence of SHAM revealed eight new sensitive isolates $(46,61,74$, $75,76,91,95$, and 118$)$ in addition to the seven isolates $(1,4,7,9,19$, 28 , and 29) from preliminary screening with $\mathrm{EC}_{50}$ values $<100 \mu \mathrm{g} / \mathrm{ml}$ for both fungicides. The 15 sensitive isolates had mean MGI of $59.1 \pm$ $7.0 \%$ (range $=43.8$ to $68.7 \%$ ) and $54.8 \pm 8.1 \%$ (range $=41.1$ to $69.2 \%$ ) to azoxystrobin and fenamidone, respectively. The remaining 108 isolates had a mean inhibition of $17.3 \pm 7.2 \%$ (range $=$ no inhibition to $36.3 \%$ inhibition) for azoxystrobin and $9.36 \pm 5.5 \%$ (range $=$ no inhibition to $27.8 \%$ inhibition) for fenamidone and were regarded as resistant (Table 5). Interestingly, two isolates (9 and 19) from preliminary azoxystrobin and fenamidone screening and one isolate (74) from the discriminatory dose assay had between 40 and $50 \%$ mycelial inhibition for both fungicides in the presence of the discriminatory dose. All other isolates regarded as sensitive had $>50 \%$ inhibition (Table 5). Therefore, these three isolates $(9,19$, and 74) were considered moderately resistant based on discriminatory dose screening.

Spore germination. Initial assays conducted with 10 C. cassiicola tomato isolates in the presence and absence of SHAM revealed no difference in germ tube elongation across repeated experiments (Table 3). Based on results of the MGI assays, 12 sensitive (1, 4, $7,28,29,46,61,75,76,91,94$, and 118), three moderately resistant $(9,19$ and 74$)$, and three resistant isolates $(2,17$, and 119) were selected for SG assays. All three resistant isolates exhibited $<50 \%$ germ tube inhibition for both 1 and $10 \mu \mathrm{g} / \mathrm{ml}$ in the presence of both fungicides. Twelve sensitive isolates were confirmed as sensitive, with $>50 \%$ inhibition to 1 and $10 \mu \mathrm{g} / \mathrm{ml}$ of azoxystrobin, with germ tube inhibition ranging from 51.8 to $91.2 \%$ for $1 \mu \mathrm{g} / \mathrm{ml}$ and a range of 61.3 to $97.1 \%$ for $10 \mu \mathrm{g} / \mathrm{ml}$. Eleven out of 12 sensitive isolates were confirmed as sensitive to fenamidone, with a germ tube inhibition range of 51.3 to $83.4 \%$ for $1 \mu \mathrm{g} / \mathrm{ml}$ and a range of 65.1 to $93.9 \%$ for $10 \mu \mathrm{g} / \mathrm{ml}$. Three isolates $(9,19$, and 74$)$ for azoxystrobin and four isolates $(4,9,19$, and 74$)$ from fenamidone were considered moderately resistant in SG assays with $<50 \%$ inhibition at $1 \mu \mathrm{g} / \mathrm{ml}$ and $>50 \%$ inhibition at $10 \mu \mathrm{g} / \mathrm{ml}$. Germ tube growth inhibition ranged from 27.4 to $31.1 \%$ and 62.0 to $66.0 \%$ for 1 and $10 \mu \mathrm{g} / \mathrm{ml}$ of azoxystrobin, respectively. Relative tube inhibition ranged from 19.6 to $33.6 \%$ and 54.7 to $67.5 \%$ for 1 and $10 \mu \mathrm{g} / \mathrm{ml}$ of fenamidone, respectively.

\section{AZOXYSTROBIN}

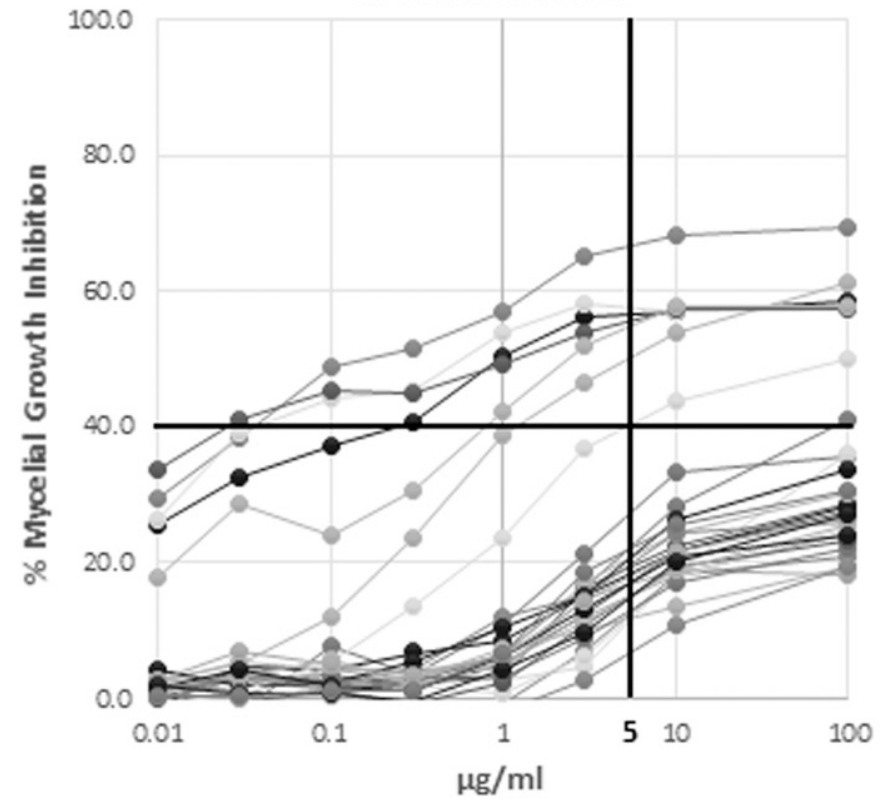

PCR-RFLP analysis and sequencing. Amplification of the cytb region with the primer pair cct-cytb-F and cct-cytb-R resulted in a 346-bp fragment from genomic DNA. Digestion of the $c y t b$ amplified product and visualization by electrophoresis produced two fragments (approximately 225 and $125 \mathrm{bp}$ ) among 108 isolates, and the remaining 15 isolates were left undigested as a single 346-bp fragment. The 15 isolates lacking the Fnu4HI restriction site in $c y t b$ corresponded to isolates rated as either sensitive or moderately resistant in MGI and SG assays. The 18 isolates included in SG assays were sequenced to confirm the presence of G143A in resistant isolates

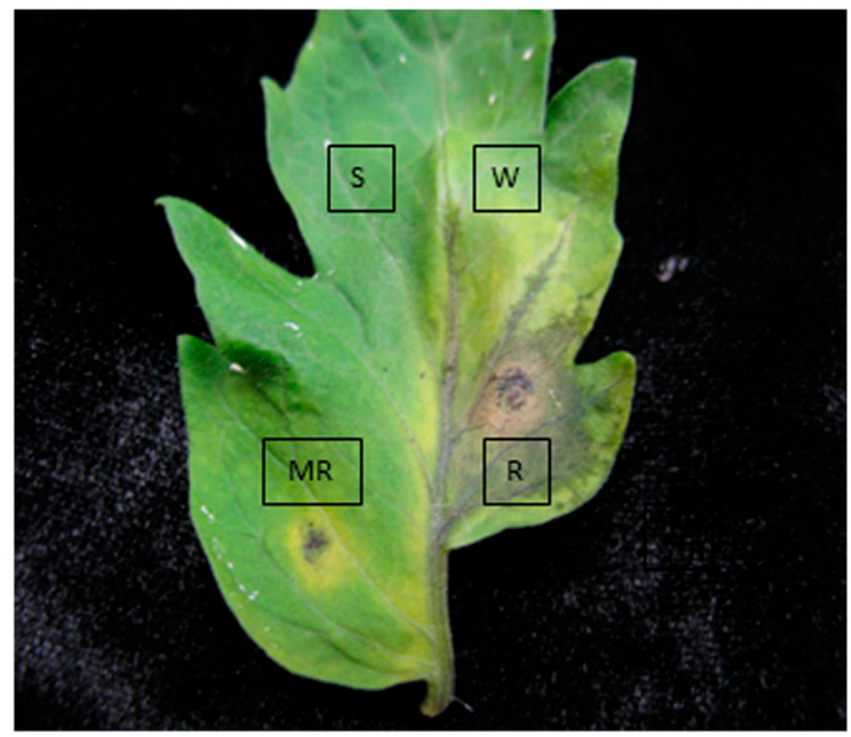

Fig. 3. Detached leaflet treated with Quadris Flowable (Syngenta; azoxystrobin $22.9 \%$ a.i.) $24 \mathrm{~h}$ before inoculation with three Corynespora cassiicola tomato isolates $(19,93$, and 125). One sensitive isolate (S) (125), one moderately resistant isolate (MR) (19), one resistant isolate $(R)(93)$, and a water control (W) were applied to the abaxial leaf surface of the leaflet as $7-\mu$ l droplets. Detached leaflet responses to $C$. cassiicola infection are marked accordingly in the figure. Pictures were taken after 1 week in a humidity chamber.

Fig. 2. Dose-response curves from preliminary sensitivity screening of 29 Corynespora cassiicola isolates (Table 4$)$ and arbitrary selection of a discriminatory dose $(5 \mu \mathrm{g} / \mathrm{ml})$ indicated by the vertical black line. The horizontal black line indicates $40 \% \mathrm{MGI}$, which was used to distinguish sensitive isolates ( $>50 \%)$ from moderately resistant ( 40 to $50 \%$ ) and resistant isolates $(>50 \%)$ in discriminatory dose screening for azoxystrobin and fenamidone. 
Table 5. Percentage mycelial growth inhibition (\%MGI) results of 123 Corynespora cassiicola isolates collected from tomato in Florida on half-strength PDA amended with a discriminatory dose $(5 \mu \mathrm{g} / \mathrm{ml})$ of azoxystrobin or fenamidone compared with a nonamended control and $F n u 4 \mathrm{HI}$ amplicon digestion results

\begin{tabular}{|c|c|c|c|c|c|c|}
\hline \multirow[b]{2}{*}{ Isolate number } & \multirow[b]{2}{*}{ Isolate name } & \multirow[b]{2}{*}{ County of origin } & \multirow[b]{2}{*}{ Sensitivity ratingy } & \multirow[b]{2}{*}{ Fnu $4 \mathrm{HI}^{\mathrm{z}}$} & \multicolumn{2}{|c|}{$\%$ MGI $^{\mathbf{x}}$} \\
\hline & & & & & Azoxystrobin + SHAM & $\overline{\text { Fenamidone + SHAM }}$ \\
\hline 1 & GEV3124 & Hendry & $\mathrm{S}$ & ND & 68.7 & 69.2 \\
\hline 2 & GEV3125 & Hendry & $\mathrm{R}$ & $\mathrm{D}$ & 20.6 & 12.8 \\
\hline 3 & GEV3126 & Hendry & $\mathrm{R}$ & $\mathrm{D}$ & 12.7 & 10.3 \\
\hline 4 & GEV3127 & Hendry & $\mathrm{S}$ & ND & 60.2 & 59.8 \\
\hline 5 & GEV3128 & Hendry & $\mathrm{R}$ & $\mathrm{D}$ & 15.5 & 13.1 \\
\hline 6 & GEV3129 & Hendry & $\mathrm{R}$ & $\mathrm{D}$ & 2.1 & 0.0 \\
\hline 7 & GEV3130 & Manatee & $\mathrm{S}$ & ND & 64.2 & 64.3 \\
\hline 8 & GEV3131 & Manatee & $\mathrm{R}$ & $\mathrm{D}$ & 11.4 & 6.0 \\
\hline 9 & GEV3132 & Manatee & MR & ND & 45.6 & 41.1 \\
\hline 10 & GEV3133 & Manatee & $\mathrm{R}$ & $\mathrm{D}$ & 4.4 & 13.1 \\
\hline 11 & GEV3134 & Manatee & $\mathrm{R}$ & $\mathrm{D}$ & 1.8 & 10.7 \\
\hline 12 & GEV3135 & Hillsborough & $\mathrm{R}$ & $\mathrm{D}$ & 8.7 & 11.6 \\
\hline 13 & GEV3136 & Hillsborough & $\mathrm{R}$ & $\mathrm{D}$ & 14.9 & 11.6 \\
\hline 14 & GEV3137 & Collier & $\mathrm{R}$ & $\mathrm{D}$ & 13.6 & 8.3 \\
\hline 15 & GEV3138 & Collier & $\mathrm{R}$ & $\mathrm{D}$ & 17.6 & 12.7 \\
\hline 16 & GEV3139 & Collier & $\mathrm{R}$ & $\mathrm{D}$ & 6.1 & 8.9 \\
\hline 17 & GEV3140 & Collier & $\mathrm{R}$ & $\mathrm{D}$ & 12.0 & 1.6 \\
\hline 18 & GEV3141 & Palm Beach & $\mathrm{R}$ & $\mathrm{D}$ & 14.5 & 6.2 \\
\hline 19 & GEV3142 & Palm Beach & MR & ND & 43.8 & 41.8 \\
\hline 20 & GEV3143 & Palm Beach & $\mathrm{R}$ & $\mathrm{D}$ & 10.0 & 10.5 \\
\hline 21 & GEV3144 & Martin & $\mathrm{R}$ & $\mathrm{D}$ & 12.7 & 8.2 \\
\hline 22 & GEV3145 & Martin & $\mathrm{R}$ & $\mathrm{D}$ & 12.4 & 5.7 \\
\hline 23 & GEV3147 & Collier & $\mathrm{R}$ & $\mathrm{D}$ & 10.2 & 4.9 \\
\hline 24 & GEV3148 & Collier & $\mathrm{R}$ & $\mathrm{D}$ & 14.3 & 9.2 \\
\hline 25 & GEV3150 & Collier & $\mathrm{R}$ & $\mathrm{D}$ & 11.9 & 11.6 \\
\hline 26 & GEV3151 & Collier & $\mathrm{R}$ & $\mathrm{D}$ & 16.2 & 11.8 \\
\hline 27 & GEV3153 & Hillsborough & $\mathrm{R}$ & $\mathrm{D}$ & 19.2 & 17.7 \\
\hline 28 & GEV3154 & Gadsden & $\mathrm{S}$ & ND & 64.2 & 62.2 \\
\hline 29 & GEV3155 & Suwannee & $\mathrm{S}$ & ND & 63.1 & 58.2 \\
\hline 30 & GEV3156 & Hendry & $\mathrm{R}$ & $\mathrm{D}$ & 21.1 & 6.2 \\
\hline 31 & GEV3157 & Hendry & $\mathrm{R}$ & $\mathrm{D}$ & 28.1 & 11.9 \\
\hline 32 & GEV3158 & Hendry & $\mathrm{R}$ & $\mathrm{D}$ & 19.8 & 11.7 \\
\hline 33 & GEV3159 & Hendry & $\mathrm{R}$ & $\mathrm{D}$ & 22.5 & 6.1 \\
\hline 34 & GEV3160 & Hendry & $\mathrm{R}$ & $\mathrm{D}$ & 22.1 & 7.5 \\
\hline 35 & GEV3161 & Hendry & $\mathrm{R}$ & $\mathrm{D}$ & 20.7 & 5.1 \\
\hline 36 & GEV3162 & Hendry & $\mathrm{R}$ & $\mathrm{D}$ & 17.6 & 5.8 \\
\hline 37 & GEV3163 & Hendry & $\mathrm{R}$ & $\mathrm{D}$ & 17.9 & 6.0 \\
\hline 38 & GEV3164 & Hendry & $\mathrm{R}$ & $\mathrm{D}$ & 24.3 & 8.7 \\
\hline 39 & GEV3165 & Hendry & $\mathrm{R}$ & $\mathrm{D}$ & 19.7 & 12.9 \\
\hline 40 & GEV3166 & Hendry & $\mathrm{R}$ & $\mathrm{D}$ & 17.0 & 7.4 \\
\hline 41 & GEV3167 & Hendry & $\mathrm{R}$ & $\mathrm{D}$ & 11.8 & 5.6 \\
\hline 42 & GEV3168 & Hendry & $\mathrm{R}$ & $\mathrm{D}$ & 15.3 & 6.5 \\
\hline 43 & GEV3169 & Hendry & $\mathrm{R}$ & $\mathrm{D}$ & 18.0 & 5.3 \\
\hline 44 & GEV3170 & Hendry & $\mathrm{R}$ & $\mathrm{D}$ & 21.0 & 4.8 \\
\hline 45 & GEV3171 & Hendry & $\mathrm{R}$ & $\mathrm{D}$ & 14.4 & 11.6 \\
\hline 46 & GEV3172 & Hendry & $\mathrm{S}$ & ND & 56.3 & 51.2 \\
\hline 47 & GEV3173 & Hendry & $\mathrm{R}$ & $\mathrm{D}$ & 19.2 & 6.1 \\
\hline 48 & GEV3174 & Hendry & $\mathrm{R}$ & $\mathrm{D}$ & 15.5 & 8.5 \\
\hline 49 & GEV3175 & Hendry & $\mathrm{R}$ & $\mathrm{D}$ & 16.9 & 5.9 \\
\hline 50 & GEV3176 & Hendry & $\mathrm{R}$ & $\mathrm{D}$ & 16.0 & 8.8 \\
\hline 51 & GEV3177 & Hendry & $\mathrm{R}$ & $\mathrm{D}$ & 2.1 & 5.5 \\
\hline 52 & GEV3178 & Manatee & $\mathrm{R}$ & $\mathrm{D}$ & 13.6 & 4.4 \\
\hline 53 & GEV3179 & Manatee & $\mathrm{R}$ & $\mathrm{D}$ & 8.6 & 6.3 \\
\hline 54 & GEV3180 & Manatee & $\mathrm{R}$ & $\mathrm{D}$ & 14.2 & 5.5 \\
\hline 55 & GEV3181 & Manatee & $\mathrm{R}$ & $\mathrm{D}$ & 14.8 & 6.0 \\
\hline 56 & GEV3182 & Manatee & $\mathrm{R}$ & $\mathrm{D}$ & 12.4 & 6.9 \\
\hline 57 & GEV3183 & Manatee & $\mathrm{R}$ & $\mathrm{D}$ & 22.5 & 11.1 \\
\hline 58 & GEV3184 & Manatee & $\mathrm{R}$ & $\mathrm{D}$ & 12.0 & 4.1 \\
\hline 59 & GEV3185 & Manatee & $\mathrm{R}$ & $\mathrm{D}$ & 11.3 & 8.8 \\
\hline 60 & GEV3186 & Manatee & $\mathrm{R}$ & $\mathrm{D}$ & 24.8 & 10.6 \\
\hline
\end{tabular}

(Continued on next page)

$\mathrm{x} \%$ MGI was calculated for isolates exposed to the discriminatory dose $(5 \mu \mathrm{g} / \mathrm{ml})$ relative to the controls. Azoxystrobin and fenamidone discriminatory doses were derived from Quadris 20.8 FL and Reason 500 SC, respectively. SHAM, salicylhydroxamic acid.

y Based on percentage inhibition values of $>50 \%$ for sensitive (S), between 40 and $50 \%$ for moderately resistant (MR) isolates, and $<40 \%$ for resistant (R) isolates. ${ }^{\mathrm{z}} \mathrm{Cytb}$ amplicon is digested (D) or not digested (ND) by Fnu4HI, a mutation-specific restriction enzyme modified to cleave amplicons containing the G143A substitution, responsible for complete QoI resistance. 
Table 5. (Continued from previous page)

\begin{tabular}{|c|c|c|c|c|c|c|}
\hline \multirow[b]{2}{*}{ Isolate number } & \multirow[b]{2}{*}{ Isolate name } & \multirow[b]{2}{*}{ County of origin } & \multirow[b]{2}{*}{ Sensitivity ratingy } & \multirow[b]{2}{*}{ Fnu4HI ${ }^{\mathrm{z}}$} & \multicolumn{2}{|c|}{$\%$ MGIx } \\
\hline & & & & & Azoxystrobin + SHAM & Fenamidone + SHAM \\
\hline 61 & GEV3187 & Manatee & $\mathrm{S}$ & ND & 65.0 & 54.2 \\
\hline 62 & GEV3188 & Manatee & $\mathrm{R}$ & $\mathrm{D}$ & 21.6 & 4.4 \\
\hline 63 & GEV3189 & Collier & $\mathrm{R}$ & $\mathrm{D}$ & 7.0 & 11.3 \\
\hline 64 & GEV3190 & Collier & $\mathrm{R}$ & $\mathrm{D}$ & 28.5 & 7.6 \\
\hline 65 & GEV3191 & Collier & $\mathrm{R}$ & $\mathrm{D}$ & 8.9 & 3.5 \\
\hline 66 & GEV3192 & Collier & $\mathrm{R}$ & $\mathrm{D}$ & 22.0 & 10.1 \\
\hline 67 & GEV3193 & Collier & $\mathrm{R}$ & $\mathrm{D}$ & 15.1 & 4.4 \\
\hline 68 & GEV3194 & Collier & $\mathrm{R}$ & $\mathrm{D}$ & 19.6 & 6.5 \\
\hline 69 & GEV3195 & Collier & $\mathrm{R}$ & $\mathrm{D}$ & 7.4 & 14.3 \\
\hline 70 & GEV3196 & Collier & $\mathrm{R}$ & $\mathrm{D}$ & 15.7 & 10.1 \\
\hline 71 & GEV3198 & Palm Beach & $\mathrm{R}$ & $\mathrm{D}$ & 18.4 & 3.3 \\
\hline 72 & GEV3199 & Palm Beach & $\mathrm{R}$ & $\mathrm{D}$ & 19.7 & 14.1 \\
\hline 73 & GEV3200 & Palm Beach & $\mathrm{R}$ & $\mathrm{D}$ & 15.8 & 5.6 \\
\hline 74 & GEV3202 & Palm Beach & MR & ND & 47.8 & 42.5 \\
\hline 75 & GEV3203 & Palm Beach & $\mathrm{S}$ & ND & 63.0 & 53.5 \\
\hline 76 & GEV3204 & Martin & $\mathrm{S}$ & ND & 55.8 & 56.0 \\
\hline 77 & GEV3205 & Martin & $\mathrm{R}$ & $\mathrm{D}$ & 36.3 & 5.9 \\
\hline 78 & GEV3206 & Martin & $\mathrm{R}$ & $\mathrm{D}$ & 24.3 & 6.6 \\
\hline 79 & GEV3207 & Collier & $\mathrm{R}$ & $\mathrm{D}$ & 14.0 & 15.6 \\
\hline 80 & GEV3208 & Collier & $\mathrm{R}$ & $\mathrm{D}$ & 13.3 & 5.7 \\
\hline 81 & GEV3209 & Collier & $\mathrm{R}$ & $\mathrm{D}$ & 17.0 & 7.2 \\
\hline 82 & GEV3210 & Collier & $\mathrm{R}$ & $\mathrm{D}$ & 9.3 & 4.2 \\
\hline 83 & GEV3211 & Collier & $\mathrm{R}$ & $\mathrm{D}$ & 18.3 & 3.1 \\
\hline 84 & GEV3212 & Collier & $\mathrm{R}$ & $\mathrm{D}$ & 16.2 & 6.7 \\
\hline 85 & GEV3213 & Collier & $\mathrm{R}$ & $\mathrm{D}$ & 15.0 & 5.3 \\
\hline 86 & GEV3214 & Collier & $\mathrm{R}$ & $\mathrm{D}$ & 12.2 & 9.0 \\
\hline 87 & GEV3215 & Collier & $\mathrm{R}$ & $\mathrm{D}$ & 13.2 & 6.1 \\
\hline 88 & GEV3216 & Collier & $\mathrm{R}$ & $\mathrm{D}$ & 13.7 & 7.8 \\
\hline 89 & GEV3219 & Hillsborough & $\mathrm{R}$ & $\mathrm{D}$ & 23.9 & 4.2 \\
\hline 90 & GEV3220 & Hillsborough & $\mathrm{R}$ & $\mathrm{D}$ & 23.2 & 2.8 \\
\hline 91 & GEV3221 & Gadsden & $\mathrm{S}$ & ND & 60.0 & 50.1 \\
\hline 92 & GEV3222 & Hillsborough & $\mathrm{R}$ & $\mathrm{D}$ & 18.2 & 7.8 \\
\hline 93 & GEV3223 & Hillsborough & $\mathrm{R}$ & $\mathrm{D}$ & 22.7 & 17.8 \\
\hline 94 & GEV3224 & Hillsborough & $\mathrm{R}$ & $\mathrm{D}$ & 9.1 & 4.4 \\
\hline 95 & GEV3225 & Hillsborough & $\mathrm{S}$ & ND & 66.3 & 60.7 \\
\hline 96 & GEV3226 & Hillsborough & $\mathrm{R}$ & $\mathrm{D}$ & 26.0 & 15.1 \\
\hline 97 & GEV3227 & Hillsborough & $\mathrm{R}$ & $\mathrm{D}$ & 18.4 & 8.4 \\
\hline 98 & GEV3228 & Hillsborough & $\mathrm{R}$ & $\mathrm{D}$ & 17.5 & 6.1 \\
\hline 99 & GEV3229 & Hillsborough & $\mathrm{R}$ & $\mathrm{D}$ & 18.6 & 3.9 \\
\hline 100 & GEV3230 & Hillsborough & $\mathrm{R}$ & $\mathrm{D}$ & 34.6 & 17.8 \\
\hline 101 & GEV3231 & Collier & $\mathrm{R}$ & $\mathrm{D}$ & 31.3 & 4.4 \\
\hline 102 & GEV3232 & Hillsborough & $\mathrm{R}$ & $\mathrm{D}$ & 17.4 & 6.2 \\
\hline 103 & GEV3233 & Hillsborough & $\mathrm{R}$ & $\mathrm{D}$ & 20.1 & 8.3 \\
\hline 104 & GEV3234 & Hillsborough & $\mathrm{R}$ & $\mathrm{D}$ & 29.0 & 17.0 \\
\hline 105 & GEV3235 & Hillsborough & $\mathrm{R}$ & $\mathrm{D}$ & 29.0 & 20.2 \\
\hline 106 & GEV3236 & Hillsborough & $\mathrm{R}$ & $\mathrm{D}$ & 16.6 & 25.0 \\
\hline 107 & GEV3237 & Hillsborough & $\mathrm{R}$ & $\mathrm{D}$ & 28.7 & 18.0 \\
\hline 108 & GEV3238 & Hillsborough & $\mathrm{R}$ & $\mathrm{D}$ & 29.8 & 20.2 \\
\hline 109 & GEV3239 & Hillsborough & $\mathrm{R}$ & $\mathrm{D}$ & 20.7 & 12.6 \\
\hline 110 & GEV3240 & Hillsborough & $\mathrm{R}$ & $\mathrm{D}$ & 34.5 & 18.9 \\
\hline 111 & GEV3241 & Hillsborough & $\mathrm{R}$ & $\mathrm{D}$ & 24.1 & 9.4 \\
\hline 112 & GEV3242 & Hillsborough & $\mathrm{R}$ & $\mathrm{D}$ & 21.5 & 13.0 \\
\hline 113 & GEV3243 & Hillsborough & $\mathrm{R}$ & $\mathrm{D}$ & 31.8 & 19.2 \\
\hline 114 & GEV3244 & Hillsborough & $\mathrm{R}$ & $\mathrm{D}$ & 27.4 & 18.4 \\
\hline 115 & GEV3245 & Hillsborough & $\mathrm{R}$ & $\mathrm{D}$ & 19.0 & 10.5 \\
\hline 116 & GEV3246 & Hillsborough & $\mathrm{R}$ & $\mathrm{D}$ & 29.4 & 19.9 \\
\hline 117 & GEV3247 & Hillsborough & $\mathrm{R}$ & $\mathrm{D}$ & 30.0 & 27.8 \\
\hline 118 & GEV3248 & Hillsborough & $\mathrm{S}$ & ND & 56.7 & 56.8 \\
\hline 119 & GEV3249 & Hillsborough & $\mathrm{R}$ & $\mathrm{D}$ & 19.4 & 14.1 \\
\hline 120 & GEV3250 & Hillsborough & $\mathrm{R}$ & $\mathrm{D}$ & 20.8 & 15.3 \\
\hline 121 & GEV3251 & Hillsborough & $\mathrm{R}$ & $\mathrm{D}$ & 17.6 & 12.7 \\
\hline 122 & GEV3252 & Hillsborough & $\mathrm{R}$ & $\mathrm{D}$ & 7.1 & 12.3 \\
\hline 123 & GEV3253 & Hillsborough & $\mathrm{R}$ & $\mathrm{D}$ & 20.7 & 15.6 \\
\hline
\end{tabular}


and potentially observe the presence of any minor mutations (Table 6). Sequence alignment of the predicted $c y t b$ gene from the whole-genome sequence of $C$. cassiicola UM591 revealed several different single-nucleotide polymorphisms. A nucleotide change from GGT to GCT, corresponding to amino acid 143 in cytb, conferred a substitution of $\mathrm{G}$ with $\mathrm{A}$ in all three isolates $(2,17$, and 119) rated resistant to azoxystrobin and fenamidone in MGI and SG assays. A nucleotide change of TTC to TTA corresponding to amino acid position 129 caused an F-to-L substitution and was identified in isolates 9,19 , and 74 that were characterized as moderately

Table 6. Characterization of fungicide resistance based on mean spore GTI, restriction enzyme digestion, and sequencing results of 18 C. cassiicola isolates used in SG assays

\begin{tabular}{|c|c|c|c|c|c|c|}
\hline \multirow[b]{2}{*}{ Isolate number } & \multicolumn{2}{|c|}{ Azoxystrobin } & \multicolumn{2}{|c|}{ Fenamidone } & \multirow[b]{2}{*}{$C y t b^{\mathbf{y}}$} & \multirow[b]{2}{*}{ Fnu4HI } \\
\hline & Dose $(\mu \mathrm{g} / \mathrm{ml})$ & \% GTI ${ }^{x}$ (Stdev) & Dose $(\mu \mathrm{g} / \mathrm{ml})$ & \%GTI (Stdev) & & \\
\hline \multirow[t]{3}{*}{1} & & & & & WT & ND \\
\hline & 1 & $90.2( \pm 4.2)$ & 1 & $75.1( \pm 10.0)$ & & \\
\hline & 10 & $92.9( \pm 5.4)$ & 10 & $88.5( \pm 8.6)$ & & \\
\hline \multirow[t]{3}{*}{28} & & & & & & ND \\
\hline & 1 & $61.5( \pm 6.5)$ & 1 & $57.9( \pm 4.7)$ & S-162 & \\
\hline & 10 & $71.2( \pm 4.7)$ & 10 & $65.1( \pm 9.2)$ & & \\
\hline \multirow[t]{3}{*}{97} & & & & & WT & ND \\
\hline & 1 & $91.2( \pm 5.1)$ & 1 & $83.4( \pm 5.7)$ & & \\
\hline & 10 & $97.1( \pm 3.2)$ & 10 & $93.9( \pm 7.1)$ & & \\
\hline \multirow[t]{3}{*}{75} & & & & & WT & ND \\
\hline & 1 & $83.5( \pm 6.0)$ & 1 & $58.3( \pm 12.1)$ & & \\
\hline & 10 & $88.7( \pm 6.6)$ & 10 & $85.2( \pm 2.8)$ & & \\
\hline \multirow[t]{3}{*}{118} & & & & & WT & ND \\
\hline & 1 & $82.8( \pm 3.1)$ & 1 & $63.9( \pm 10.5)$ & & \\
\hline & 10 & $90.7( \pm 5.8)$ & 10 & $87.1( \pm 1.9)$ & & \\
\hline \multirow[t]{3}{*}{7} & & & & & WT & ND \\
\hline & 1 & $81.7( \pm 16.6)$ & 1 & $61.7( \pm 13.9)$ & & \\
\hline & 10 & $90.0( \pm 8.7)$ & 10 & $87.7( \pm 11.0)$ & & \\
\hline \multirow[t]{3}{*}{61} & & & & & WT & ND \\
\hline & 1 & $77.0( \pm 8.3)$ & 1 & $60.2( \pm 6.9)$ & & \\
\hline & 10 & $83.0( \pm 8.5)$ & 10 & $75.6( \pm 8.0)$ & & \\
\hline \multirow[t]{3}{*}{76} & & & & & WT & ND \\
\hline & 1 & $73.0( \pm 16.9)$ & 1 & $54.4( \pm 5.2)$ & & \\
\hline & 10 & $87.6( \pm 7.6)$ & 10 & $77.1( \pm 9.8)$ & & \\
\hline \multirow[t]{3}{*}{91} & & & & & S-162 & ND \\
\hline & 1 & $67.3( \pm 5.7)$ & 1 & $51.3( \pm 4.9)$ & & \\
\hline & 10 & $76.2( \pm 8.1)$ & 10 & $73.9( \pm 6.9)$ & & \\
\hline \multirow[t]{3}{*}{46} & & & & & S-162 & ND \\
\hline & 1 & $67.8( \pm 6.4)$ & 1 & $58.5( \pm 4.9)$ & & \\
\hline & 10 & $72.4( \pm 5.6)$ & 10 & $66.1( \pm 10.0)$ & & \\
\hline \multirow[t]{3}{*}{29} & & & & & S-162 & ND \\
\hline & 1 & $86.8( \pm 7.7)$ & 1 & $71.9( \pm 10.9)$ & & \\
\hline & 10 & $89.9( \pm 2.5)$ & 10 & $85.1( \pm 3.6)$ & & \\
\hline \multirow[t]{3}{*}{4} & & & & & S-162 & ND \\
\hline & 1 & $51.8( \pm 7.8)$ & 1 & $33.6( \pm 3.2)$ & & \\
\hline & 10 & $61.3( \pm 9.3)$ & 10 & $56.4( \pm 7.1)$ & & \\
\hline \multirow[t]{3}{*}{19} & & & & & F129L & ND \\
\hline & 1 & $31.1( \pm 7.5)$ & 1 & $22.5( \pm 9.4)$ & & \\
\hline & 10 & $66.0( \pm 15.3)$ & 10 & $67.5( \pm 10.9)$ & & \\
\hline 74 & & & & & F129L & ND \\
\hline & 1 & $27.4( \pm 15.5)$ & 1 & $19.6( \pm 14.9)$ & & \\
\hline & 10 & $60.7( \pm 8.1)$ & 10 & $54.7( \pm 21.8)$ & & \\
\hline 9 & & & & & F129L & ND \\
\hline & 1 & $29.1( \pm 5.7)$ & 1 & $31.0( \pm 6.3)$ & & \\
\hline & 10 & $62.0( \pm 10.8)$ & 10 & $60.4( \pm 10.3)$ & & \\
\hline 2 & & & & & G143A & $\mathrm{D}$ \\
\hline & 1 & $4.2( \pm 4.5)$ & 1 & $7.0( \pm 11.9)$ & & \\
\hline & 10 & $7.5( \pm 9.3)$ & 10 & $3.7( \pm 5.4)$ & & \\
\hline 17 & & & & & G143A & $\mathrm{D}$ \\
\hline & 1 & $7.9( \pm 10.4)$ & 1 & $9.5( \pm 7.0)$ & & \\
\hline & 10 & $12.1( \pm 7.4)$ & 10 & $15.6( \pm 16.9)$ & & \\
\hline 119 & & & & & G143A & $\mathrm{D}$ \\
\hline & 1 & $21.6( \pm 11.8)$ & 1 & $10.0( \pm 8.9)$ & & \\
\hline & 10 & $30.8( \pm 12.7)$ & 10 & $11.8( \pm 7.3)$ & & \\
\hline
\end{tabular}


resistant in MGI and SG assays for both fungicides. Isolate 4, which was identified as sensitive based on MGI and moderately resistant based on SG toward fenamidone, contained a previously undocumented silent mutation (S-162), which was also present in five isolates $(4,28,29,46$, and 91) from cotton, sesame, and tomato, regarded as sensitive to both in vitro assays (Table 6). Seven tomato isolates $(1,7,61,75,76,95$, and 118) lacked mutations in the cytb gene relative to the reference sequence.

Detached leaflet assay. Results from detached leaflet assays (DLAs; Fig. 3) identified two sensitive isolates (7 and 125), with no predicted amino acid substitutions present in $c y t b$, that were inhibited by 72 and $74 \%$ in the presence of azoxystrobin and 48 and $65 \%$ in the presence of fenamidone. Two moderately resistant isolates (19 and 79) were inhibited by 26 and $31 \%$ in the presence of azoxystrobin and 36 and $43 \%$ in the presence of fenamidone. Two resistant isolates ( 2 and 93 ) were inhibited by $10 \%$ or enhanced by $3 \%$ in the presence of azoxystrobin, and in the presence of fenamidone both resistant isolates increased in disease severity by 3 and $15 \%$ (Table 7 ).

\section{Discussion}

Reduced performance of QoI fungicides (specifically, azoxystrobin) for the management of target spot on Florida tomatoes has been documented in several field trials over the last 15 years (Paret et al. 2013; Pernezny et al. 1996, 2002; G. E. Vallad, personal communication). It is difficult to find tomato fields not exposed to QoI fungicides in Florida, because these chemistries account for a

Table 7. Detached leaflet assay (DLA) results of six C. cassiicola tomato isolates conducted in the presence and absence of each individual quinone outside inhibitor $(\mathrm{QoI})$ fungicide

\begin{tabular}{|c|c|c|c|c|c|}
\hline \multirow{2}{*}{$\begin{array}{l}\text { Isolate } \\
\text { number }\end{array}$} & \multirow[b]{2}{*}{ Sensitivity ${ }^{y}$} & \multicolumn{2}{|c|}{$\begin{array}{l}\text { Azoxystrobin } \\
(0.44 \mathrm{~kg} / \mathrm{ha})^{\mathrm{x}}\end{array}$} & \multicolumn{2}{|c|}{$\begin{array}{l}\text { Fenamidone } \\
(0.29 \text { kg/ha) }\end{array}$} \\
\hline & & Untreated & Treated $^{\mathbf{z}}$ & Untreated & Treated \\
\hline 2 & $\mathrm{R}$ & 3.8 & 3.9 & 3.9 & 4.5 \\
\hline 93 & $\mathrm{R}$ & 4.2 & 3.8 & 3.9 & 4.0 \\
\hline 19 & MR & 3.8 & $2.8^{*}$ & 4.2 & $2.4^{*}$ \\
\hline 79 & MR & 3.9 & $2.7 *$ & 2.8 & $1.8^{*}$ \\
\hline 7 & $\mathrm{~S}$ & 3.1 & $0.8^{*}$ & 2.6 & $0.9 *$ \\
\hline 125 & $S$ & 1.8 & $0.5^{*}$ & 2.1 & $1.1 *$ \\
\hline Water & - & 0.1 & 0.1 & 0.0 & 0.0 \\
\hline
\end{tabular}

${ }^{x}$ Fungicide concentrations are presented as kilograms of active ingredient (a.i.) per hectare at the highest labeled broadcast volume for field-grown tomatoes in Florida (280 liter/ha). Azoxystrobin and fenamidone mixtures were made from Quadris 20.8 FL and Reason 500 SC, respectively.

${ }^{y}$ Sensitivity refers to mycelial growth inhibition (MGI) and spore germination (SG) results. R, resistant; MR, moderately resistant; S, sensitive.

${ }^{\mathrm{z}}$ Data are presented as lesion diameter in millimeters. Asterisks $(*)$ indicate a significant difference in lesion diameter relative to the untreated control for each individual compound. significant portion of commercial fungicides labeled for use on tomato. Because of widespread QoI use and no fungicide application history for our isolate population, a true baseline for QoI sensitivity could not be established in this study. However, a recent study conducted on $C$. cassiicola cucumber isolates revealed that sensitive $\mathrm{EC}_{50}$ values based on MGI ranged from 0.68 to $2.30 \mu \mathrm{g} / \mathrm{ml}$ in the presence of azoxystrobin + SHAM (Duan et al. 2019). These values are not dissimilar to the $\mathrm{EC}_{50}$ values of QoI-sensitive isolates exposed to azoxystrobin + SHAM in this study $(0.2$ to $1.8 \mu \mathrm{g} / \mathrm{ml})$.

In the presence of SHAM $(100 \mu \mathrm{g} / \mathrm{ml})$, MGI based on a single discriminatory dose $(5 \mu \mathrm{g} / \mathrm{ml})$ was able to distinguish between resistant isolates containing the G143A substitution from moderately resistant isolates containing the F129L substitution, from sensitive isolates lacking any amino acid substitutions. SG assays could also clearly differentiate resistant, moderately resistant, and sensitive isolates in azoxystrobin and fenamidone screening. However, one isolate (4) did appear moderately resistant to fenamidone in SG assays but contained only a silent mutation relative to the reference sequence (S162). Although it is known that QoI fungicides are more effective at inhibiting fungal SG than mycelium growth (Balba 2007; Mondal et al. 2005; Pasche et al. 2004), several studies have used an MGI assay to determine sensitivity to QoI fungicides, including one conducted on C. cassiicola cucumber isolates (Avila-Adame et al. 2003; Banno et al. 2009; Ishii et al. 2007).

Two QoI-sensitive isolates, two QoI-moderately resistant isolates, and two QoI-resistant isolates subjected to azoxystrobin and fenamidone in DLAs corroborated results from MGI, SG, and sequencing. In DLAs, disease severity of resistant isolates did not differ from that of untreated controls; however, sensitive and moderately resistant isolates had significantly lower disease severity than untreated controls for each separate fungicide formulation (Table 7). Therefore, isolate sensitivity of $C$. cassiicola to QoI fungicides from our population can be readily distinguished by MGI by use of a single discriminatory concentration or by restriction enzyme analysis, both more rapid approaches for isolate sensitivity characterization.

To date, no SG assays have been conducted on C. cassiicola in the presence of fungicides. Evaluation of SG in various other phytopathogenic fungi has been based on a binary (yes/no) system of germinated versus nongerminated conidia for the strobilurin fungicides (Fontaine et al. 2009; Hincapie et al. 2014; Kim et al. 2003; Pasche et al. 2004) because of their inherent ability to inhibit SG (Balba 2007; Vincelli 2002). However, some tomato isolates in our collection produced conidia readily, whereas others did not. Spores from some isolates had irregular tube lengths because of the variability in spore size and a lack of developmental uniformity among isolates. For example, a smaller, underdeveloped conidium could produce equal tube length to a much larger, more developed conidium from the same isolate. This created a challenge in the development of a binary evaluation for $C$. cassiicola; however, relative mean tube length provided clear distinctions of characteristic groupings. Therefore, mean tube length was calculated for each isolate-treatment-dose combination, and relative tube length inhibition (\%) was generated

Table 8. Frequency of resistance to azoxystrobin and fenamidone and county distribution of 123 C. cassiicola isolates collected from 2015 to 2017 in Florida

\begin{tabular}{|c|c|c|c|c|c|c|}
\hline County & No. of isolates & Host & Resistant & Moderately resistant & Sensitive & Frequency of resistance ${ }^{y}$ \\
\hline Hendry & 28 & Tomato & 25 & - & 3 & $89.3 \%$ \\
\hline Collier & 27 & Tomato & 27 & - & - & $100 \%$ \\
\hline Hillsborough & 33 & Tomato & 31 & - & 2 & $93.9 \%$ \\
\hline Hillsborough & 3 & Cucumber & 3 & - & - & $100 \%$ \\
\hline Manatee & 16 & Tomato & 12 & 1 & 3 & $81.3 \%$ \\
\hline Palm Beach & 8 & Tomato & 3 & 2 & 3 & $62.5 \%$ \\
\hline Martin & 5 & Tomato & 4 & - & 1 & $80.0 \%$ \\
\hline Gadsden & 2 & Cotton ${ }^{\mathrm{z}}$ & - & - & 2 & $0 \%$ \\
\hline Suwannee & 1 & Sesame $z$ & - & - & 1 & $0 \%$ \\
\hline Total & 123 & - & 108 & 3 & 12 & $87.8 \%$ \\
\hline
\end{tabular}

${ }^{y}$ Frequency of resistance refers to isolates regarded as moderately resistant and resistant to quinone outside inhibitor (QoI) fungicides in that county based on mycelial growth inhibition (MGI) results corroborated by spore germination (SG), restriction enzyme digestion, and detached leaflet assays (DLAs).

${ }^{z}$ Cotton and sesame $C$. cassiicola isolates were collected by Dr. Nicholas Dufault at University of Florida, Gainesville, FL. 
by normalizing both doses ( 1 and $10 \mu \mathrm{g} / \mathrm{ml}$ ) to the control for each separate experiment.

Fenamidone was introduced in this study to assess levels of resistance in a nonstrobilurin QoI fungicide compared with a strobilurin QoI fungicide, azoxystrobin. Although azoxystrobin and fenamidone have the same mode of action, they are structurally very different compounds (Bartlett et al. 2002). In addition, other components in the formulation could affect fungal growth; therefore, comparisons should not be made between fungicides, only relative differences between isolates to each fungicide.

Previous studies have identified several pathogens in which the G143A mutation cannot occur (Banno et al. 2009; Hily et al. 2011; Hincapie et al. 2014; Sierotzki et al. 2007) because of either the presence of a group I intron two nucleotides downstream of amino acid position 143 in the cytb gene (Hincapie et al. 2014) or a mutation in noncoding regions upstream of position 143 (De La Salle et al. 1982). Therefore, if the G143A mutation occurs, it will interfere with the splicing process, producing a deficient $c y t b$ and therein a lethal mutant (Burke 1988; Grasso et al. 2006). In this study, no mutations in noncoding sequences or the presence of type I introns after position 143 in $c y t b$ were identified in any of the sequenced isolates. This finding implies a lack of interference with the splicing process, and therefore C. cassiicola tomato isolates in our population with the G143A mutation have complete resistance to QoI fungicides and can exist in nature.

The in vitro results for the 123 C. cassiicola isolates collected for this study indicate widespread resistance to QoI fungicides in Florida. All 108 isolates with either the G143A or F129L substitution are distributed throughout six counties at a rate of $\geq 62.5 \%$, up to $100 \%$ in one county (Table 8 ). The 12 isolates lacking any mutation or containing silent mutations were documented in all counties, indicating the presence of sensitive and resistant isolates in the same sampling locations throughout the state (Table 8). It is possible that sensitive C. cassiicola isolates are surviving in plant debris (Oliveira et al. 2012; Sarma and Nayudu 1971) or arriving from a distance by wind dispersal. Three isolates $(26,87$, and 88 ) collected in early 2016 from organic tomato production fields in Immokalee, Florida still appeared resistant to QoI fungicides based on MGI and contained the G143A substitution in CytB.

The use of QoI fungicides in Florida tomato fields has sharply declined in the last decade, because of growers' reports of resistance and paralleled recommendations to limit further resistance development. Mixing or interchanging resistance-prone fungicides with fungicides from a different mode of action can limit the development of fungicide resistance (Staub 1991); however, several QoI fungicides (FRAC \#11) are formulated as mixtures with different modes of action, including the succinate dehydrogenase inhibitors (SDHIs) (FRAC \#7), demethylation inhibitors (FRAC \#3), and one unknown mode of action (FRAC \#27). These mixtures are often considered "broad spectrum" by chemical companies and growers. Widespread QoI resistance in Florida raises concern for the utility of these mixtures and selection of resistance to their fungicidal counterparts. In the presence of QoI resistance, the complimentary FRAC group becomes the solitary mechanism for control, which may accelerate resistance development to additional modes of action. Dual resistance to QoIs and SDHIs has been reported for Botrytis cinerea (Veloukas et al. 2014) and has potential to form in C. cassiicola based on reports of resistance in cucumber to SDHI fungicides via mutations in the SDH protein complex (Miyamoto et al. 2010) and studies that identified QoI resistance to $C$. cassiicola cucumber isolates based on mutations in cytb (Ishii et al. 2007).

Two studies have identified a great amount of morphological and genetic diversity among $C$. cassiicola isolates collected from tomato (Dixon et al. 2009; Sumabat et al. 2018). Diversity in colony morphology was also observed among $C$. cassiicola isolates in our population, which led to molecular identification using ITS from our eight most morphologically diverse tomato isolates and five nonhost isolates, confirming $C$. cassiicola in all cases (Table 1). Our results align with studies performed on $C$. cassiicola and fellow Pleosporales pathogens such as Alternaria alternata, Didymella
(Stagonosporopsis) bryoniae, and Venturia inaequalis that have correlated complete QoI resistance with the G143A mutation (Finger et al. 2013; Ishii et al. 2007; Lesniak et al. 2011; Ma and Michailides, 2004). With the molecular mechanisms of QoI resistance elucidated (Gisi et al. 2002; Grasso et al. 2006; Kuck 2007) and a multitude of studies indicating a direct correlation between single point mutations in cytb and QoI resistance (Fernández-Ortuño et al. 2008; Ishii 2008; Ma and Michailides 2005), we feel confident in a characterization based on in vitro methods and corroboration of corresponding mutations.

This is the first large-scale characterization of $C$. cassiicola isolates from tomato conducted in Florida. Results from this study may also be applicable to the recent emergence of $C$. cassiicola in cotton and soybean throughout the southeastern United States, which similarly use QoI fungicides for disease management. The diverse nature of this pathogen and grower reliance on fungicides for target spot control on tomato and other crops suggest that additional studies are necessary to investigate resistance development in other labeled fungicide groups and ultimately limit disease losses through enhanced spray recommendations.

\section{Acknowledgments}

We are very grateful of the cooperation of tomato growers and crop consultants in Florida for field surveys and isolate collection, and the efforts of Dr. Mathews Paret for providing isolates from North Florida

\section{Literature Cited}

Adkison, H. M., Margenthaler, E., Burlacu, V., Willis, R., and Vallad, G. E. 2012. Occurrence of resistance to respiratory inhibitors in Corynespora cassiicola isolates from Florida tomatoes. 2012 APS Annual Meeting. Phytopathology 102:1.

Avila-Adame, C., Olaya, G., and Köller, W. 2003. Characterization of Colletotrichum graminicola isolates resistant to strobilurin-related QoI fungicides. Plant Dis. 87: $1426-1432$.

Balba, H. 2007. Review of strobilurin fungicide chemicals. J. Environ. Sci. Health Part B 42:441-451.

Banno, S., Yamashita, K., Fukumori, F., Okada, K., Uekusa, H., Takagaki, M., Kimura, M., and Fujimura, M. 2009. Characterization of QoI resistance in Botrytis cinerea and identification of two types of mitochondrial cytochrome b gene. Plant Pathol. 58:120-129.

Bartlett, D. W., Clough, J. M., Godwin, J. R., Hall, A. A., Hamer, M., and ParrDobrzanski, B. 2002. The strobilurin fungicides. Pest Manag. Sci. 58:649-662.

Blazquez, C. H. 1972. Target spot of tomato. Plant Dis. Rep. 56:243.

Bradley, C. A., and Pedersen, D. K. 2011. Baseline sensitivity of Cercospora zeaemaydis to quinone outside inhibitor fungicides. Plant Dis. 95:189-194.

Burke, J. M. 1988. Molecular genetics of group I introns: RNA structures and protein factors required for splicing - a review. Gene 73:273-294.

Date, H., Kataoka, E., Tanina, K., Sasaki, S., Inoue, K., Nasu, H., and Kasuyama, S. 2004. Sensitivity of Corynespora cassiicola, causal agent of Corynespora leaf spot of cucumber, to thiophanate-methyl, diethofencarb and azoxystrobin. Jpn. J. Phytopathol. 70:10-13.

De La Salle, H., Jacq, C., and Slonimski, P. P. 1982. Critical sequences within mitochondrial introns: pleiotropic mRNA maturase and cis-dominant signals of the box intron controlling reductase and oxidase. Cell 28:721-732.

Dellaporta, S. L., Wood, J., and Hicks, J. B. 1983. A plant DNA minipreparation: Version II. Plant Mol. Biol. Rep. 1:19-21.

Dixon, L. J., Schlub, R. L., Pernezny, K., and Datnoff, L. E. 2009. Host specialization and phylogenetic diversity of Corynespora cassiicola. Phytopathology 99:1015-1027.

Duan, Y., Xin, W., Lu, F., Li, T., Li, M., Wu, J., Wang, J., and Zhou, M. 2019 Benzimidazole- and QoI-resistance in Corynespora cassiicola populations from greenhouse-cultivated cucumber: an emerging problem in China. Pestic. Biochem. Physiol. 153:95-105.

Ellis, M. B. 1957. Some species of Corynespora. CMI Mycol. Pap. 65:1-16.

Fajola, A. O. 1979. The post-harvest fruit rots of tomato (Lycopersicum esculentum) in Nigeria. Mol. Nutr. Food Res. 23:105-109.

Fernández-Ortuño, D., Torés, J. A., De Vicente, A., and Pérez-García, A. 2008. Mechanisms of resistance to QoI fungicides in phytopathogenic fungi. Int. Microbiol. 11:1.

Finger, M. J., Stevenson, K. L., and Ji, P. 2013. Stability of azoxystrobin resistance and fitness of fungicide-sensitive and -resistant field isolates of Didymella bryoniae. Phytopathology 103:43-44.

Fontaine, S. R. F., Fraissinet-Tachet, L., Micoud, A. M. R., and Melayah, D. 2009 Monitoring of Venturia inaequalis harbouring the QoI resistance G143A mutation in French orchards as revealed by PCR assays. Pestic. Sci. 65:74-81.

FRAC (Fungicide Resistance Action Committee). 2014. Pathogen risk list. Published online by FRAC. www.frac.info.

FRAC (Fungicide Resistance Action Committee). 2015. QoI fungicides Introduction and general information. Published online by FRAC www.frac.info. 
FRAC (Fungicide Resistance Action Committee). 2017. FRAC code list: fungicides sorted by mode of action (including FRAC code numbering). Published online by FRAC. www.frac.info.

Gisi, U., Sierotzki, H., Cook, A., and McCaffery, A. 2002. Mechanisms influencing the evolution of resistance to Qo inhibitor fungicides. Pest Manag. Sci. 58:859-867.

Grasso, V., Palermo, S., Sierotzki, H., Garibaldi, A., and Gisi, U. 2006. Cytochrome $\mathrm{b}$ gene structure and consequences for resistance to Qo inhibitor fungicides in plant pathogens. Pest Manag. Sci. 62:465-472.

Hall, T., Biosciences, I., and Carlsbad, C. 2011. BioEdit: an important software for molecular biology. GERF Bull. Biosci. 2:60-61.

Hily, J. M., Singer, S. D., Villani, S. M., and Cox, K. D. 2011. Characterization of the cytochrome b (cyt b) gene from Monilinia species causing brown rot of stone and pome fruit and its significance in the development of QoI resistance. Pest Manag. Sci. 67:385-396.

Hincapie, M., Wang, N. Y., Peres, N. A., and Dewdney, M. M. 2014. Baseline sensitivity of Guignardia citricarpa isolates from Florida to azoxystrobin and pyraclostrobin. Plant Dis. 98:780-789.

Ishii, H. 2006. Impact of fungicide resistance in plant pathogens on crop disease control and agricultural environment. Jpn. Agric. Res. Q. JARQ 40:205-211.

Ishii, H. 2008. Fungicide research in Japan —an overview. Pages 11-17 in: Modern fungicides and antifungal compounds V: 15th International Reinhardsbrunn Symposium, Friedrichroda, Germany, May 6-10, 2007. Deutsche Phytomedizinische Gesellschaft eV Verlag, Braunschweig, Germany.

Ishii, H. 2009. QoI fungicide resistance: current status and the problems associated with DNA-based monitoring. Pages 37-45 in: Recent Developments in Management of Plant Diseases. U. Gisi, I. Chet, and M. L. Gullino, eds. Springer Netherlands, Dordrecht, The Netherlands.

Ishii, H., Yano, K., Date, H., Furuta, A., Sagehashi, Y., Yamaguchi, T., and Hasama, W. 2007. Molecular characterization and diagnosis of QoI resistance in cucumber and eggplant fungal pathogens. Phytopathology 97:1458-1466.

Keinath, A. P. 2009. Sensitivity to azoxystrobin in Didymella bryoniae isolates collected before and after field use of strobilurin fungicides. Pest Manag. Sci. 65:1090-1096

Kim, Y. S., Dixon, E. W., Vincelli, P., and Farman, M. L. 2003. Field resistance to strobilurin (QoI) fungicides in Pyricularia grisea caused by mutations in the mitochondrial cytochrome b gene. Phytopathology 93:891-900.

Kuck, K. H. 2007. Pages 275-283 in: QoI Fungicides: Resistance Mechanisms and Its Practical Importance. Pesticide Chemistry. Crop Protection, Public Health, Environmental Safety. H. Ohkawa, H. Miyagawa, and P. W. Lee, eds. WILEY-VCH, Weinheim, Germany.

Lesniak, K. E., Proffer, T. J., Beckerman, J. L., and Sundin, G. W. 2011. Occurrence of QoI resistance and detection of the G143A mutation in Michigan populations of Venturia inaequalis. Plant Dis. 95:927-934.

Luo, C. X., and Schnabel, G. 2008. Adaptation to fungicides in Monilinia fructicola isolates with different fungicide resistance phenotypes. Phytopathology 98:230-238.

Ma, Z., Felts, D., and Michailides, T. J. 2003. Resistance to azoxystrobin in Alternaria isolates from pistachio in California. Pestic. Biochem. Physiol. 77: 66-74.

Ma, Z., and Michailides, T. J. 2004. An allele-specific PCR assay for detecting azoxystrobin-resistant Alternaria isolates from pistachio in California. J. Phytopathol. 152:118-121.

Ma, Z., and Michailides, T. J. 2005. Advances in understanding molecular mechanisms of fungicide resistance and molecular detection of resistant genotypes in phytopathogenic fungi. Crop Prot. 24:853-863.

MacKenzie, K. J., Sumabat, L. G., Xavier, K. V., and Vallad, G. E. 2018. A review of Corynespora cassiicola and its increasing relevance to tomato in Florida. Plant Health Prog. 19:303-309.

Madhavi, G. B., and Murthy, K. V. M. 2001. Effect of temperature and pH on spore germination and germ tube growth of Corynespora cassiicola (Berk. and Curt.) wei. causing leaf spot disease on blackgram. Agric. Sci. Dig. 21:75-78

McIntosh, L. 1994. Molecular biology of the alternative oxidase. Plant Physiology 105:781.

Miyamoto, T., Ishii, H., Seko, T., Kobori, S., and Tomita, Y. 2009. Occurrence of Corynespora cassiicola isolates resistant to boscalid on cucumber in Ibaraki Prefecture, Japan. Plant Pathol. 58:1144-1151.

Miyamoto, T., Ishii, H., Seko, T., Tomita, Y., Kobori, S., and Ogawara, T. 2007. Occurrence of boscalid-resistant isolates of cucumber Corynespora leaf spot fungus (C. cassiicola). Jpn. J. Phytopathol. 74:37-38.
Miyamoto, T., Ishii, H., Stammler, G., Koch, A., Ogawara, T., Tomita, Y., and Kobori, S. 2010. Distribution and molecular characterization of Corynespora cassiicola isolates resistant to boscalid. Plant Pathol. 59:873-881.

Mondal, S. N., Bhatia, A., Shilts, T., and Timmer, L. W. 2005. Baseline sensitivities of fungal pathogens of fruit and foliage of citrus to azoxystrobin, pyraclostrobin, and fenbuconazole. Plant Dis. 89:1186-1194.

Oliveira, R. R., Aguiar, B. D. M., Tessmann, D. J., Pujade-Renaud, V., and Vida J. B. 2012. Chlamydospore formation by Corynespora cassiicola. Trop. Plant Pathol. 37:415-418.

Paret, M. L., Ritchie, L., Olson, S. M., and Vallad, G. E. 2013. Target spot on tomatoes: fungicide resistance and effective fungicide programs in Florida in 2011-2012. Acta Hortic. 1069:25-28.

Pasche, J. S., Piche, L. M., and Gudmestad, N. C. 2005. Effect of the F129L mutation in Alternaria solani on fungicides affecting mitochondrial respiration. Plant Dis. 89:269-278

Pasche, J. S., Wharam, C. M., and Gudmestad, N. C. 2004. Shift in sensitivity of Alternaria solani in response to QoI fungicides. Plant Dis. 88:181-187.

Pernezny, K., Datnoff, L. E., Mueller, T., and Collins, J. 1996. Losses in freshmarket tomato production in Florida due to target spot and bacterial spot and the benefits of protectant fungicides. Plant Dis. 80:559-563.

Pernezny, K., Stoffella, P., Collins, J., Carroll, A., and Beaney, A. 2002. Control of target spot of tomato with fungicides, systemic acquired resistance activators, and a biocontrol agent. Plant Protect. Sci. 38:81-88.

Qi, Y. X., Zhang, X., Pu, J. J., Liu, X. M., Lu, Y., Zhang, H., Zhang, H. Q., Lv, Y. C., and Xie, Y. X. 2011. Morphological and molecular analysis of genetic variability within isolates of Corynespora cassiicola from different hosts. Eur. J. Plant Pathol. 130:83-95.

Sarma, Y. R., and Nayudu, M. V. 1971. Corynespora leaf spot of brinjal. Proc. Indian Acad. Sci. B. 74:92-97.

Schlub, R. L., Smith, L. J., Datnoff, L. E., and Pernezny, K. 2007. An overview of target spot of tomato caused by Corynespora cassiicola. Acta Hortic. 808: 25-28.

Secor, G. A., and Rivera, V. V. 2012. Fungicide resistance assays for fungal plant pathogens. Pages 385-392 in: Plant Fungal Pathogens. M. D. Bolton and B. P. H. J. Thomma, eds. Humana Press, Totowa, NJ.

Sierotzki, H., Frey, R., Wullschleger, J., Palermo, S., Karlin, S., Godwin, J., and Gisi, U. 2007. Cytochrome b gene sequence and structure of Pyrenophora teres and $P$. tritici-repentis and implications for QoI resistance. Pest Manag. Sci. 63:225-233

Sierotzki, H., Parisi, S., Steinfeld, U., Tenzer, I., Poirey, S., and Gisi, U. 2000 Mode of resistance to respiration inhibitors at the cytochrome bc1 enzyme complex of Mycosphaerella fijiensis field isolates. Pest. Manage. Sci. 56: 833-841.

Staub, T. 1991. Fungicide resistance: practical experience with antiresistance strategies and the role of integrated use. Annu. Rev. Phytopathol. 29: 421-442.

Sumabat, L., Kemerait, R. C., and Brewer, M. T. 2018. Phylogenetic diversity and host specialization of Corynespora cassiicola responsible for emerging target spot disease of cotton and other crops in the southeastern United States. Phytopathology. 108:892-901

Vallad, G. E., Smith, H. A., Dittmar, P. J., and Freeman, J. H. 2017. Vegetable Production Handbook of Florida, 2017-2018. UF/IFAS Extension, Gainesville, FL

Vawdrey, L. L., Grice, K. R. E., and Westerhuis, D. 2008. Field and laboratory evaluations of fungicides for the control of brown spot (Corynespora cassiicola) and black spot (Asperisporium caricae) of papaya in far north Queensland, Australia. Australas. Plant Pathol. 37:552-558.

Veloukas, T., Kalogeropoulou, P., Markoglou, A. N., and Karaoglanidis, G. S. 2014. Fitness and competitive ability of Botrytis cinerea field isolates with dual resistance to SDHI and QoI fungicides, associated with several sdh B and the cyt b G143A mutations. Phytopathology 104:347-356.

Vincelli, P. 2002. QoI (strobilurin) fungicides: benefits and risks. Plant Health Instructor. doi:10.1094/PHI-I-2002-0809-02

Weber, R. W., and Hahn, M. 2011. A rapid and simple method for determining fungicide resistance in Botrytis. J. Plant Dis. Prot. 118:17-25.

White, T. J., Bruns, T., Lee, S., and Taylor, J. 1990. Amplification and direct sequencing of fungal ribosomal RNA genes for phylogenetics. Pages 315-322 in: PCR Protocols: A Guide to Methods and Applications 18. M. A. Innis, D. H. Gelfand, J. J. Sninsky, and T. J. White, eds. Academic Press, San Diego, CA. 